DOI: $10.6060 / \mathrm{mhc} 170724 \mathrm{k}$

\title{
Synthesis of Benzihemiporphyrazine Bearing tert-Butylquinoxaline[2,3-c]pyrrole Fragments
}

\author{
Svetlana V. Alekseeva, Alexandra S. Kuznetsova, ${ }^{@ 1}$ Oscar I. Koifman, \\ and Mikhail K. Islyaikin ${ }^{\circledR 2}$
}

Dedicated to Academician Aslan Yusupovich Tsivadze on the occasion of his 75-th birthday

IRLoN, Research Institute of Macroheterocycles, Ivanovo State University of Chemistry and Technology, 153000 Ivanovo, Russia

${ }^{\circledR 1}$ Corresponding author E-mail: kuznetsova.alex.91@gmail.com

${ }^{\circledR 2}$ Corresponding authorE-mail: islyaikin@isuct.ru

\begin{abstract}
A new representative macroheterocyclic compound of the ABAB-type was synthesized by crossover-condensation of m-phenylenediamine and 6-tert-butylquinoxaline-2,3-dicarbonitrile by refluxing in fresh distillated $\mathrm{BuOH}$. The crude product was washed by hot hexane and purified by column chromatography on silica gel using an eluent mixture comprised of methylene chloride:methanol:hexane. Solvents were then evaporated and orange powder was dried at reduced pressure. The obtained substance was characterized by UV-Vis, IR, ${ }^{1} H$ NMR spectroscopy and massspectrometry data. The signal located at $655.5 \mathrm{Da}$ which corresponds to $[M+H]^{+}$ions was detected in MALDI-TOF (without matrix). Using of $\alpha$-cyano-4-hydroxycinnamic acid (CHCA) as matrix induces the appearance of a reduced form of the macrocycle which is detected by a signal at $656 \mathrm{Da}[\mathrm{M}+2 \mathrm{H}]^{+}$. The structures of two regioisomers with different positions of tert-butyl groups in pyrroloquinoxaline fragments were optimized at DFT/B3LYP/6-31G(d,p) level. It was predicted that both isomers have nonplanar saddle-shape structures and that the cis-isomer was found to be of $0.75 \mathrm{kcal} / \mathrm{mol}$ more stable than alternative regioisomer. The positive values of NICS calculated at the centers of molecules confirm the nonaromatic character of their macrorings.
\end{abstract}

Keywords: Synthesis, macroheterocyclic compound, benzihemiporphyrazine, m-phenylenediamine, 6-tert-butylquinoxaline-2,3-dicarbonitrile.

\section{Синтез бензигемипорфиразина с фрагментами трет-бутилхиноксалин[2,3-c]пиррола}

\author{
С. В. Алексеева, А. С. Кузнецова, ${ }^{\circledR 1}$ О. И. Койфмман, М. К. Исляйкин ${ }^{\circledR 2}$
}

Международная научно-исследовательская лаборатория наноматериалов, НИИ химии макрогетерочиклов,

Ивановский государственньй химико-технологический университет, 153000 Иваново, Россия

${ }^{@ 1}$ E-mail: kuznetsova.alex.91@gmail.com

@2E-mail: islyaikin@isuct.ru

Взаимодействием м-фенилендиамина и 6-трет-бутилхиноксалин-2,3-дикарбонитрила в кипящем бутаноле было получено макрогетероциклическое соединение АВАВ-типа. Очистку проводили промыванием горячим гексаном и далее колоночной хроматографией на силикагеле с использованием элюирующей смеси: хлористый метилен:метанол:гексан. После отгонки растворителей оранжевый порошок сушили в вакууме. Полученное соединение охарактеризовано данными электронной, ИК, ${ }^{1}$ Н ЯМР спектроскопии и масс-спектрометрии. В масс-спектре MALDI-TOF (без использования матрицы) обнаружен сигнал 655.5 Да, соответствуюший молекулярному иону $[\mathrm{M}+\mathrm{H}]^{+}$. Использование а-цииано-4-гидроксикоричной кислоть (СНСА) в качестве матрицы индуцирует появление восстановленной формы макроцикла с сигналом 656 Да $[\mathrm{M}+2 \mathrm{H}]^{+}$. Cтруктуры 
двух региоизомеров, содержащих трет-бутильные группы в различных положениях хиноксалиновых фрагментов, оптимизированы методом DFT/B3LYP/6-31G(d,p). Показано, что оба изомера имеют неплоское седлообразное строение, при этом ичис-изомер оказался на 0.75 ккал/моль энергетически более устойчивым, чем альтернативный региоизомер. Положительные значения NICS, вычисленные для центров молекул, подтверждают неароматический характер макрокольияа.

Ключевые слова: Синтез, макрогетероциклическое соединение, бензигемипорфиразин, $м$-фенилендиамин, 6-трет-бутилхиноксалин-2,3-дикарбонитрил.

\section{Introduction}

Pyrazino-annelated phthalocyanines (Pcs) have attracted much attention. ${ }^{[1,2]}$ Indeed, they demonstrate properties which are inherent to Pcs and, moreover, the presence of auxillary nitrogen atoms which results in supplementary coordination abilities and a basic character of macroheterocyclic core. ${ }^{[3]}$ Therefore these compounds reveal a number of practically interesting properties. ${ }^{[4,5]}$

A substitution of two opposite faced isoindole moieties in Pc molecule with aromatic diamines led to ABAB-type macrosystems known as hemiporphyrazines (Hps). ${ }^{[6,7]}$ Various aspects of their synthesis, structure particularities, coordination characteristics, and practical applications have been reviewed. ${ }^{[8-11]}$ New optical limiting ${ }^{[12]}$ and photophysical properties ${ }^{[13-15]}$ of Hps have also been reported. Therefore multiloop conjugation systems, which can be highlighted in Hps molecules, stimulate considerable theoretical interest. ${ }^{[16-18]}$ Moreover, the presence of quinoxaline fragments in Mcs structure could enlarge the conjugation chain and expand their coordination abilities. However, Mcs of the ABAB-type with quinoxaline rings have not been studied due to the lack of preparative methods of their synthesis.

It's worthy to note that Mcs are typically very poorly soluble in organic solvents. The introduction of bulky substituents (tert-butyl groups, for instance) onto the periphery of macrocycle increases the solubility in common organic solvents, facilitates their purification, and opens larger areas for their application. ${ }^{[19,20]}$ Hence the subject of this work is synthesis and characterization of dibenzihemiporphyrazine of the ABAB-type with 1,3-phenylene (A) and pyrroloquinoxaline rings $(\mathrm{B})$ bearing tert-butyl groups.

\section{Experimental}

6-tert-Butylquinoxaline-2,3-dicarbonitrile has been prepared following the method described in the literature. ${ }^{[21]}$ Butanol was distillated before use. Column chromatography was carried out on silica gel Merck-60. Thin-layer chromatography (TLC) was performed on aluminum sheets precoated with aluminum oxide $60 \mathrm{~F}_{254}$ (Merck). MALDI-TOF spectra were obtained with a Shimadzu Biotech Axima Confidence in positive ion mode without matrix and using $\alpha$-cyano-4-hydroxycinnamic acid (CHCA) as matrix. Nitrogen elemental analysis was carried out with a FlashEA 1112 CHNS-O Analyzer. ${ }^{1} \mathrm{H}$ NMR spectra were recorded with

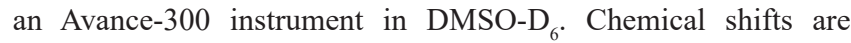
expressed in parts per million (ppm), and coupling constants $(J)$ in Hertz (Hz). IR spectra were recorded on an Avatar 360 FT-IR instrument. Quantum chemical calculations of two regioisomers with different positions of tert-butyl groups in pyrroloquinoxaline fragments were carried out at DFT/B3LYP/6-31G(d,p) level using Firefly QC package, ${ }^{[22]}$ which is partially based on the GAMESS (US) ${ }^{[23]}$ source code with full geometry optimization and with checking of optimized configurations on compliance with critical conditions. ${ }^{[24]}$ Nucleus-independent chemical shifts (NICS) were calculated at the center of macrocycle ring and at the centers of small cycles. ${ }^{[25]}$ The values were calculated by GIAO methods, ${ }^{[26]}$ incorporating in GAUSSIAN03 program complex. ${ }^{[27]}$ An initial geometry building, processing and presentation of the results were performed using the Chemcraft software package. ${ }^{[28]}$ The distortion angles between benzene or pyrroloquinoxaline fragments and middle plane of macrocycle were determined using the Mercury software package. ${ }^{[29]}$

5(6),20(21)-Di(tert-butyl)-2,9:17,24-diimino-11,15:26,30dimetheno-[c,n]-diquinoxalino-[1,6,12,17]-tetraazacyclodocosen (3). A mixture consisting of 6-tert-butylquinoxaline-2,3-dicarbonitrile $(0.24 \mathrm{~g}, 1.0 \mathrm{mmol}), m$-phenylenediamine $(0.11 \mathrm{~g}, 1.0 \mathrm{mmol})$ and fresh distillated $\mathrm{BuOH}(10 \mathrm{ml})$ was stirred under reflux for 24 hours. The reaction run was monitored by TLC. After cooling to r.t., the solvent was evaporated at reduced pressure. The crude product was washed by hot hexane and purified by column chromatography on silica gel using eluent mixture: $\mathrm{CH}_{2} \mathrm{Cl}_{2}: \mathrm{MeOH}: \mathrm{C}_{6} \mathrm{H}_{14}$ (10:1:3). After rotaevaporation of the solvents and drying at reduced pressure at $80{ }^{\circ} \mathrm{C}$ for 4 hours, a product was obtained as orange powder $(0.12 \mathrm{~g}, 0.18 \mathrm{mmol}, 34 \%$ on $\mathbf{1}) . \mathrm{R}_{\mathrm{f}}=0.94\left(\mathrm{Al}_{2} \mathrm{O}_{3}\right.$, $\mathrm{CH}_{2} \mathrm{Cl}_{2}: \mathrm{MeOH}: \mathrm{C}_{6} \mathrm{H}_{14}$ (10:1:3)). Found: $\mathrm{N} 21.40 \% . \mathrm{C}_{40} \mathrm{H}_{34} \mathrm{~N}_{10}$ requires $\mathrm{N} 21.39 \%$. $\mathrm{m} / \mathrm{z}$ (MALDI-TOF): without matrix $655.5[(\mathrm{M}$ $\left.+\mathrm{H})^{+}\right]$; CHCA matrix $656.5\left[(\mathrm{M}+2 \mathrm{H})^{+}\right]$. IR $(\mathrm{KBr}) v_{\max } \mathrm{cm}^{-1}: 624$, 798, 1083, 1165, 1255, 1454, 1604, 1678, 1737, 2854, 2922, 2954, 3329. UV-Vis $\left(\mathrm{CHCl}_{3}\right) \lambda_{\max } \mathrm{nm}: 264,346,357,416\left(\mathrm{C}=4 \cdot 10^{-4} \mathrm{M}\right)$. ${ }^{1} \mathrm{H}$ NMR $(500 \mathrm{MHz}$, DMSO-D $) \delta_{\mathrm{H}} \mathrm{ppm}: 8.39(2 \mathrm{H}, \mathrm{dd} J=9.0,2.2$ $\mathrm{Hz},), 8.27(2 \mathrm{H}, \mathrm{d} J=9.0 \mathrm{~Hz}),, 8.19(2 \mathrm{H}, \mathrm{d} J=2.1 \mathrm{~Hz}),, 7.72-7.00$ $(4 \mathrm{H}, \mathrm{m}), 6.98-6.39(4 \mathrm{H}, \mathrm{m}), 1.44(18 \mathrm{H}, \mathrm{s})$.

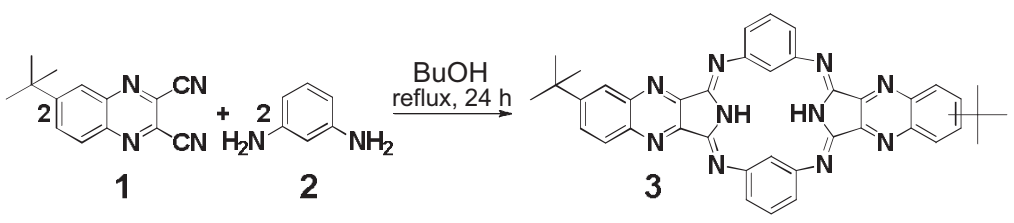

Scheme 1. 


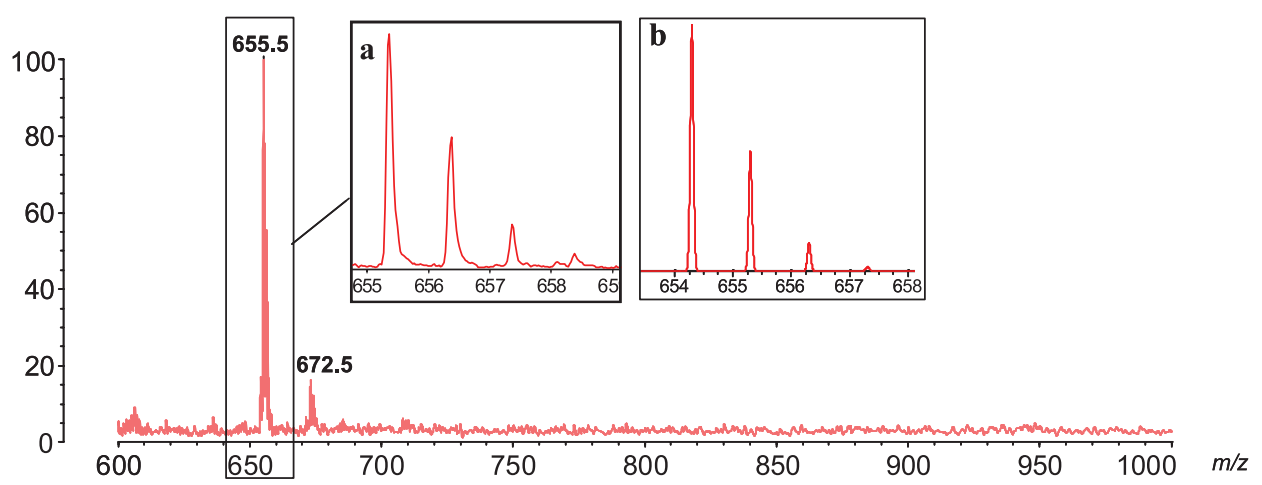

Figure 1. MALDI-TOF mass spectrum of benzihemiporphyrazine 3 (a) and its calculated isotopic distributions (b).

\section{Results and Discussion}

Following the protocol applied previously in the synthesis of the tert-butylpyrrolepyrazine macroheterocycle, ${ }^{[20]}$ compound $\mathbf{3}$ was obtained by crossover condensation of equimolecular amounts of 6-tert-butylquinoxaline-2,3dicarbonitrile $\mathbf{1}$ and $m$-phenylenediamine $\mathbf{2}$ in boiling butanol (Scheme 1).

The reaction was monitored by TLC. After 24 hours stirring at reflux, the solvent was removed under reduced pressure and the crude product was purified by column chromatography on silica gel using the eluent mixture: $\mathrm{CH}_{2} \mathrm{Cl}_{2}: \mathrm{MeOH}: \mathrm{C}_{6} \mathrm{H}_{14}$ (10:1:3). Based on the proposed synthetic scheme, the resulting orange substance is expected to be a mixture of regioisomers which differed by the tertbutyl groups positions on the pyrroloquinoxaline fragments. This mixture could not be separated under the experimental conditions.

The product was characterized by mass-spectrometry, UV-Vis, IR and ${ }^{1} \mathrm{H}$ NMR spectroscopies and elemental analysis data. Quantum chemistry calculations of the two regioisomers, which differ in the position of tert-butyl groups, were carried out at DFT level using B3LYP hybrid functional with $6-31 \mathrm{G}(\mathrm{d}, \mathrm{p})$ basis set.

The signal located at $655.5 \mathrm{Da}$ which corresponds to $[\mathrm{M}+\mathrm{H}]^{+}$ion was detected in MALDI-TOF (Figure 1). A good conformity between the calculated isotopic distributions and those derived from experimental data proves this assignment. The signal located at $672.5 \mathrm{Da}$ corresponds to $\left[\mathrm{M}+\mathrm{H}_{2} \mathrm{O}\right]^{+}$ion.

The use of $\alpha$-cyano-4-hydroxycinnamic acid as matrix induces the appearance of a reduced form of the macrocycle which can be detected by a signal at $656 \mathrm{Da}[\mathrm{M}+2 \mathrm{H}]^{+}$ in MALDI-TOF spectrum.

The main bands in the IR spectra are induced by $\mathrm{C}-\mathrm{H}$ bonds vibrations belonging to the tert-butyl group (2854, 2922, $2954 \mathrm{~cm}^{-1}$ ). The bands at 1604 and $1454 \mathrm{~cm}^{-1}$ can be correlated to deformations of $\mathrm{C}=\mathrm{C}$ and $\mathrm{C}=\mathrm{N}$ bonds, correspondingly.

Along with signals of $1.44 \mathrm{ppm}$, which result from the resonance of the protons of the tert-butyl groups, there are two groups of signals observed in the ${ }^{1} \mathrm{H}$ NMR spectrum of macrocycle measured in deuterated dimethyl sulfoxide in the region of 6.39-7.72 ppm and 8.19-8.39 ppm. These result from the resonance of the protons of the 1,3-phenylene

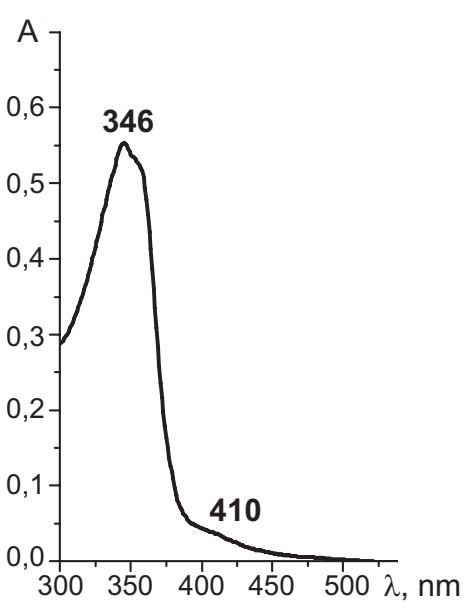

Figure 2. The UV-vis spectrum of benzihemiporphyrazine $\mathbf{3}$ in $\mathrm{CHCl}_{3}$ at $C=4 \cdot 10^{-4} \mathrm{M}$.

fragments and those of benzene nucleus of quinoxaline fragments, respectively.

The UV-Vis spectrum in chloroform contains a low intense shoulder at $416 \mathrm{~nm}$ and strong band of absorbance with maximum at $346 \mathrm{~nm}$ (Figure 2). The location of the absorbance in short-wavelength region indicates the nonaromatic character of macrocycle 3 .

To reveal the difference between regioisomers $(\mathbf{3} \mathbf{a}-$ cis, $\mathbf{3 b}-$ trans), the quantum chemistry calculations at the DFT level using B3LYP hybrid functional with 6-31G(d,p) basis set have been carried out. It was found that both $\mathbf{3} \mathbf{a}$ and $\mathbf{3 b}$ exhibit nonplanar saddle-shape structures, and $\mathbf{3 a}$ was found to be of $0.75 \mathrm{kcal} / \mathrm{mol}$ more stable than alternative regioisomer (Figure 3). The benzene and pyrroloquinoxaline fragments deviate from the median plane of molecule in opposite directions. In particular, the angles between the planes formed by the exocyclic nitrogen atoms and pyrroloquinoxaline fragments are calculated to be equal to $-26.2^{\circ}$ and $-26.7^{\circ}$, whereas the angles between the planes of benzene fragments are equal to $49.0^{\circ}$ and $49.8^{\circ}$ for $\mathbf{3 a}$ and $\mathbf{3 b}$ isomers, correspondingly. It's worthy to note the position of tert-butyl groups doesn't much affect the bond lengths and angles in macrocycle.

To analyse aromatic character of $\mathbf{3} \mathbf{a}$ and $\mathbf{3} \mathbf{b}$, the NICS values were calculated. NICS values pertaining to global 


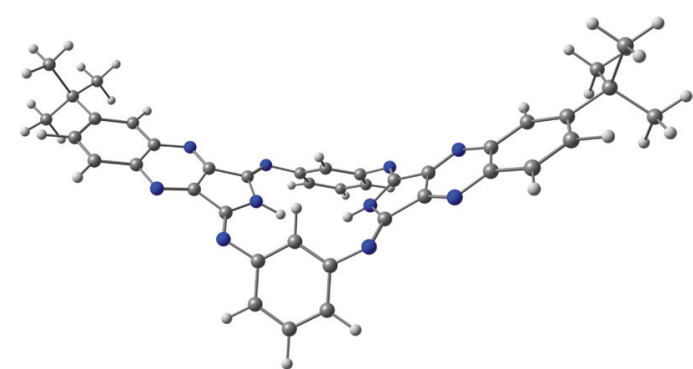

$3 a$

$\Delta E=0 \mathrm{kcal} / \mathrm{mol}$

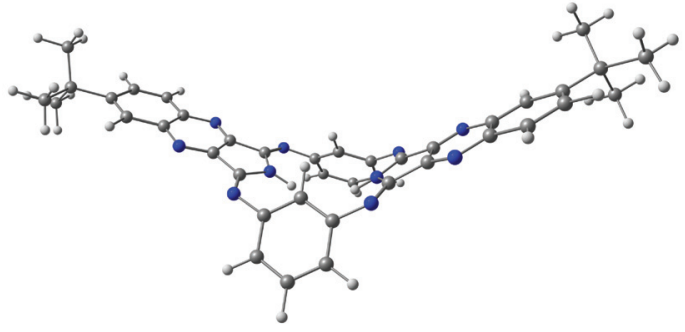

3b

$\Delta E=0.75 \mathrm{kcal} / \mathrm{mol}$

Figure 3. View of optimized configurations $\mathbf{3 a}$ and $\mathbf{3 b}$ and calculated energies.

Table 1. Calculated magnitudes of NICS (ppm) for isomers $\mathbf{3 a}$ and $\mathbf{3 b}$.

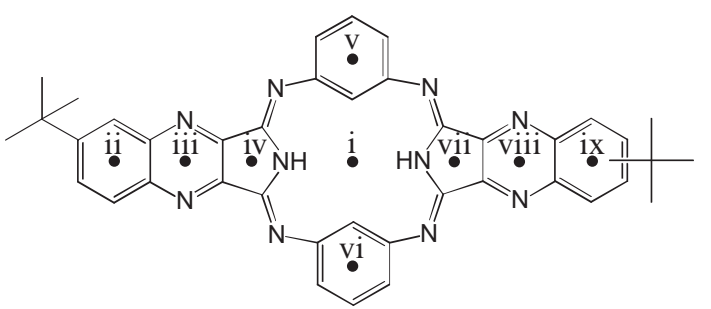

\begin{tabular}{cccccccccc}
\hline & i & ii & iii & iv & v & vi & vii & viii & ix \\
\hline 3a & 1.16 & -8.82 & -6.36 & 1.89 & -8.48 & -8.50 & 1.89 & -6.36 & -8.82 \\
3b & 1.15 & -8.86 & -6.33 & 1.89 & -8.50 & -8.51 & 1.94 & -6.24 & -9.41 \\
\hline
\end{tabular}

aromaticity were calculated at the center of the macrocycle, whereas values corresponding to local aromaticity were found at the centers of five- and six-membered rings (Table 1).

The positive values of NICS calculated at the center $\mathbf{i}$ of $\mathbf{3} \mathbf{a}$ and $\mathbf{3} \mathbf{b}$ confirm nonaromatic character of macroring. But 1,3-phenylene moieties save their aromaticity (points $\mathbf{v}$ and vi) what can be most probably explained by the fact that lost of their local aromaticities is not compensated by energy advantage when global aromaticity is established. Five-membered rings demonstrate nonaromatic character due to strong perturbations induced by double bonds located in 1,3-positions.

Analysis of orbital structure of $\mathbf{3 a}$ and $\mathbf{3} \mathbf{b}$ shows that HOMO and LUMO are orbitals of $\pi$-character and that the electron transition between them is of $\pi-\pi^{*}$-character. Computed energies of frontier orbitals and excitation energy are shown in the Table 2.

Table 2. Calculated magnitudes of HOMO/LUMO $(\mathrm{eV})$ and excitation energy $\Delta E(\mathrm{eV})$ of isomers $\mathbf{3 a}$ and $\mathbf{3 b}$.

\begin{tabular}{ccc}
\hline \multirow{2}{*}{ Orbital } & \multicolumn{2}{c}{ Energy of $\mathrm{MO}^{*}, \mathrm{eV}$} \\
\cline { 2 - 3 } & $\mathbf{3 a}$ & $\mathbf{3 b}$ \\
\hline LUMO+1 & -2.29 & -2.30 \\
LUMO & -2.32 & -2.35 \\
HOMO & -5.65 & -5.66 \\
HOMO-1 & -5.85 & -5.85 \\
$\Delta E, \mathrm{eV}$ & 3.33 & 3.31 \\
\hline
\end{tabular}

*HOMO is corresponds to $\psi_{172}, \mathrm{LUMO}-\psi_{173}$
The structures of the HOMO and LUMO of $\mathbf{3 a}$ and $\mathbf{3 b}$ are shown in Figure 4.

In order to estimate whether there is the difference in light absorption ability of the regioisomers or not, absorption spectra of $\mathbf{3} \mathbf{a}$ and $\mathbf{3} \mathbf{b}$ were calculated by TDDFT method using the configurations optimized at the B3LYP/6-31G(d,p) level. The analysis of TDDFT calculations of the first singletsinglet electron transfers showed that isomers are spectrally indistinguishable. Calculated maxima of their absorption located at $436 \mathrm{~nm}$ are nearby to that found in experimental UV-Vis spectrum of 3 (Table 3 ).

Table 3. Calculated and experimental wavelengths (nm), oscillator strengths $(f)$ for $\mathbf{3 a}$.

\begin{tabular}{cccc}
\hline $\begin{array}{c}\text { Experimental spectrum } \\
\left(\mathrm{CHCl}_{3}\right) \text { of } \mathbf{3}\end{array}$ & \multicolumn{2}{c}{$\begin{array}{c}\text { Calculated data } \\
(\text { TDDFT }) \text { of } \mathbf{3 a}\end{array}$} \\
\hline$\lambda, \mathrm{nm}$ & $\mathrm{A}$ & $\lambda, \mathrm{nm}$ & $f$ \\
\hline 416 & 0.05 & 436 & 0.15 \\
\hline
\end{tabular}

\section{Conclusions}

A new example of a benzihemiporphyrazine with tertbutyl-pyrroloquinoxaline fragments was synthesized. The product was characterized by mass-spectrometry, UV-Vis, IR and ${ }^{1} \mathrm{H}$ NMR spectroscopies, and elemental analysis data. To reveal the difference between regioisomers, quantum chemistry calculations at the DFT level using B3LYP hybrid functional with $6-31 \mathrm{G}(\mathrm{d}, \mathrm{p})$ basis set have been carried out. It was found that both cis- and trans-isomers exhibit nonplanar 
3a

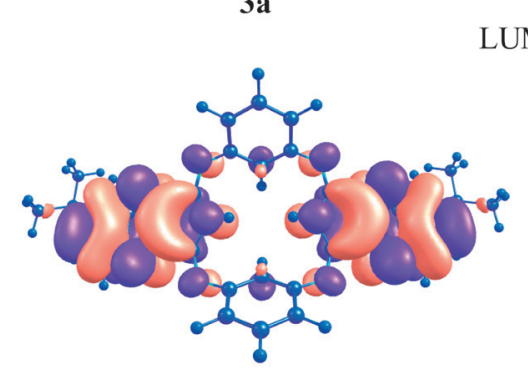

HOMO

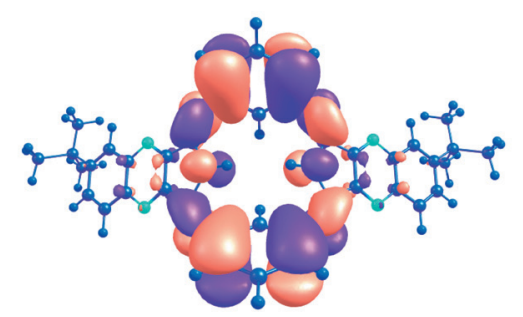

Figure 4. Views of HOMO and LUMO of $\mathbf{3} \mathbf{a}$ and $\mathbf{3 b}$.

saddle-shape structures and cis-isomer was found to be of $0.75 \mathrm{kcal} / \mathrm{mol}$ more stable than alternative regioisomer. To analyse aromatic character of isomers, the NICS values were calculated. It was shown that positive values of NICS found in the centre of molecules confirm the nonaromatic character of the macrocycle.

Acknowledgements. This work was performed thanks to the financial support from the Russian Science Foundation, grant 14-23-00204P. The study was carried out using the resources of the Center for collective use of scientific equipment of ISUCT.

\section{References}

1. Martynov A.G., Gorbunova Yu.G., Tsivadze A.Yu., Mack J., Ngoy B.P., Nyokong T. Dyes Pigm. 2017, 140, 469-479.

2. Stuzhin P.A., Ercolani C. In: The Porphyrin Handbook. Phthalocyanines: Synthesis. 2003, Vol. 15, p. 264-364.

3. Donzello M.P., Mori G., Viola E., Futur D., Fu Zh., Rizzoli C., Mannina L., Bodo E., Astolfi M.L., Ercolani C., Kadish K.M. Eur. J. Inorg. Chem. 2014, 3572-3581.

4. Zimcik P., Novakova V., Miletin M., Kopecky K. Macroheterocycles 2008, 1, 21-29.

5. Lu H., Kobayashi N. Chem. Rev. 2016, 116, 6184-6261.

6. Elvidge J.A., Linstead R.P. J. Chem. Soc. 1952, 20, 50005007.

7. Campbell J.B. Pat. 2765308 (USA). 1956.

8. Fernánrez-Lazáro F., Torres T., Hauschel B., Hanack M. Chem. Rev. 1998, 98, 563-576.

9. Rodriguez-Morgade M.S., de la Torre G., Torres T. In: The Porphyrin Handbook. Phthalocyanines: Synthesis. 2003, Vol. 15, p. 125-160.

10. Islyaikin M.K., Danilova E.A., Romanenko Yu.V., Khelevina O.G., Lomova T.N. BRILL, Leiden-Boston 2008, p. 219270.

11. Ziegler Ch.J. In: Handbook of Porphyrin Science. 2010, Vol. 17, p. 113-238.

12. Dini D., Calvete M.J.F., Hanack M., Amendolab V., Meneghetti M. Chem. Commun. 2006, 22, 2394-2396.
$3 b$

UMO
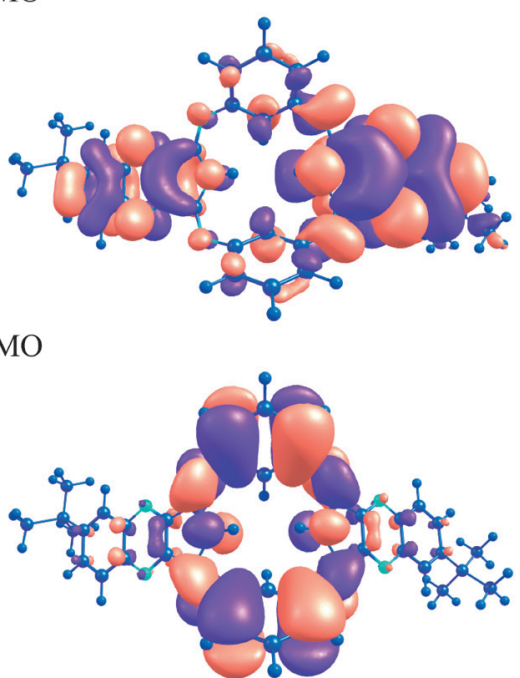

13. Persico V., Carotenuto M., Peluso A. J. Phys. Chem. A 2004, 108, 3926-3931.

14. Dini D., Calvete M.J.F., Hanack M., Amendolab V., Meneghetti M. J. Am. Chem. Soc. 2008, 130, 12290-12298.

15. Huber S.M., Seyfried M.S., Linden A., Luedtke N.W. Inorg. Chem. 2012, 51, 7032-7038.

16. Zakharov A.V., Stryapan M.G., Islyaikin M.K. THEOCHEM 2009, 906, 56.

17. Muranaka A., Ohira Sh., Hashizume D., Koshino H., Kyotani F., Hirayama M., Uchiyama M. J. Am. Chem. Soc. 2012, 134, 190-193.

18. Stryapan M.G., Islyaikin M.K. Izv. Vyssh. Uchebn. Zaved. Khim. Khim. Tekhnol. 2009, 52, 77-80.

19. Danilova E.A., Islyaikin M.K. In: Advances in Porphyrin Chemistry, Vol. 4, St. Petersburg: NII Khimii SPbGU, 2004. p. 356-375 (in Russ.) [Данилова Е.А. Исляйкин М.К. В кн.: Успехи химии порфиринов, Т. 4, Санкт-Петербург: НИИ химии СПбГУ, 2004. с. 356-375].

20. Stryapan M.G., Efimova S.V., Koifman O.I., Islyaikin M.K. Macroheterocycles 2010, 3, 38-40.

21. Efimova S.V., Korgenevskyi A.B., Koifman O.I. J. Gen. Chem. 2008, 78, 1447-1451.

22. Granovsky A.A. Firefly version 8, http://classic.chem.msu.su/ gran/firefly/index.html.

23. Schmidt M.W., Baldridge K.K., Boatz J.A., Elbert S.T., Gordon M.S., Jensen J.H., Koseki S., Matsunaga N., Nguyen K.A., Su S., Windus T.L., Dupuis M., Montgomery J.A. J. Comput. Chem. 1993, 14, 1347-1363.

24. Minkin V.I., Simkin B.J., Minyaev R.M. Quantum Chemistry of Organic Compounds. Mechanisms of Reactions. Moscow: Khimiya, 1986. 248 p. (in Russ.) [Минкин В.И., Симкин Б.Я., Миняев Р.М. Квантовая химия органических соединений. Механизмы реакций. М.: Химия, 1986].

25. Scheyer P.R., Maerker C., Dransfeld A., Jiao H., Hommes N.J.Rv.E. J. Am. Chem. Soc. 1996, 118, 6317-6318.

26. Wolinsky K., Hinton J.F., Pulay P. J. Am. Chem. Soc. 1990, $112,8251-8260$.

27. Frisch M.J., Trucks G.W., Schlegel H.B. et al. Gaussian 03, Revision C.02, Gaussian, Inc., Wallingford CT, 2004.

28. Andrienko G.A. Chemcraft, V.1.8. http://www.chemcraftprog.com.

29. Mercury. Version 3.2. http://www.ccdc.cam.ac.uk/products/ mercury.com. 